\title{
POLLINATION ECOLOGY OF RODRIGUEZIA GRANADENSIS (ORCHIDACEAE)
}

\author{
Nhora H. Ospina-Calderón ${ }^{1,2,7}$, Carol A. Dugue-Buitrago ${ }^{3}$, Raymond L. Tremblay ${ }^{4}$ \\ \& J. TUPAC OTERO ${ }^{5,6}$
}

${ }^{1}$ Departamento de Biología, Maestría en Biología-Ecología, Universidad Nacional de Colombia, Bogotá, Colombia

${ }^{2}$ Departamento de Ingeniería, Carrera de Biología, Pontificia Universidad Javeriana Cali, Colombia

${ }^{3}$ Programa de Biología. Universidad de Caldas, Manizales, Colombia

${ }^{4}$ Center for Applied Tropical Ecology and Conservation , PO Box 23360, University of Puerto Rico, Río Piedras, Puerto Rico, USA

${ }^{5}$ Departamento de Ciencias Biológicas, Universidad Nacional de Colombia, Palmira, Colombia

${ }^{6}$ Instituto de Estudios Ambientales IDEA, Palmira. Universidad Nacional de Colombia, Palmira, Colombia

${ }^{7}$ Author for correspondence: nhora_helena@yahoo.com

\begin{abstract}
Aвstract. In this paper we describe the phenotypic variation and pollination ecology of the twig orchid epiphyte Rodriguezia granadensis. The species presents flower color polymorphism (pink to white), suggesting that different color forms might be pollinated by different pollinators. To evaluate this hypothesis, one hundred plants were monitored in the field and their flowering phenology and color polymorphism was noted, two peaks of flowering were noted over the year. We evaluated the reproductive success (pollinaria removal and fruit set) and the visit of potential pollinators to both morphs. Fruit production by autogamy, geitonogamy, xenogamy, and emasculation were compared. Sugar concentration in the nectar was measured with a refractometer. Potential pollinators, euglossini bees, were attracted using methyl salicylate and eugenol. We evidenced that $R$. granadensis is pollinated by nectar-foraging euglossine bees. The fluctuation in nectar production and the scarce reproductive success among individuals suggests that the orchids may employ an attraction-deceit system as a self-mimetic or a diffuse rewarding phenomenon.
\end{abstract}

RESUMEN. En éste artículo describimos la variación fenotípica y ecología de la polinización de la epífita de ramita Rodriguezia granadensis. La especie presenta polimorfismo para el color de las flores (blanco a rosa), lo que lo llevó a hipotetizar que las diferentes formas de color pueden ser polinizadas por diferentes polinizadores. Para evaluar esta hipótesis, se monitorearon cien plantas en campo y se anotó su fenología de floración y polimorfismo en color. Dos picos de floración se presentan en el año. Evaluamos el éxito reproductivo (fitness masculino y femenino) y la visita de los polinizadores potenciales en ambos morfos. Se puso a prueba la producción de frutos por autogamia, geitonogamia, xenogamia y emasculación. La producción de néctar se midió con un refractómetro. Adicionalmente, usamos trampas de fragancia con salicilato de metilo y eugenol para atraer polinizadores potenciales (abejas euglosinas). Presentamos evidencia de la polinización de $R$. granadensis por abejas euglosinas que buscan néctar. La fluctuación en la producción de néctar y el escaso éxito reproductivo entre los individuos sugiere que la orquídea puede emplear un sistema de atracción/engaño como auto-mimetismo o un fenómeno de recompensas difusas.

KEY WORDS: self-mimetism, floral baits, deceit pollination, Euglossine bee, melitophily, reproductive success

Introduction. Floral characteristics likely arose as a consequence of natural selection and therefore are thought to be adaptive. Within species and populations, floral phenotypic traits can vary and are often perceived to vary as a consequence of pollinator-mediated selection (Ackerman 1986a, Gravendeel et al. 2004, Tremblay et al. 2005, Cuartas-Domínguez \& Medel 2010). Several studies have shown that pollinators 
can influence floral characters through selection on floral morphology (e.g. Medel et al. 2009), including orchids (Jersáková \& Kindlmann 2004, Tremblay et al. 2005). Comprehension of the pollinator interaction with floral characters and their evolutionary potential is key in understanding the origin and evolution of Angiosperms. Across the Angiosperms, certain floral characteristics are associated with particular pollinator syndromes (van der Pijl 1961). Melittophily or pollination by bees is a pollination syndrome characterized by zygomorphic flowers with contrasting colors such as yellow, white or purple, the color red is generally absent. Bee pollinated flowers present diurnal anthesis, fragrance, and nectar, although this reward is often scarce compared to other pollination syndromes (van der Pijl 1961).

It is estimated that ten percent of the orchid species, with distribution in the neotropical regions, are pollinated by euglossine bees (Roubik \& Hanson 2004). These so-called orchid-bees, are corbiculate bees of the Euglossini tribe. Both, male and females visit and pollinate a diversity of species in search of nectar, pollen, fragrances, and resins (Roubik \& Hanson 2004). Male euglossine bees are known to visit orchids to obtain fragrance rewards (androeuglossophily), but they may also seek nectar from orchids and other flowers (Roubik \& Hanson 2004). When either male or female euglossine bees visit flowers to search for nectar, they extend their proboscis and introduce it in the nectar cavity of the flower. The flowers with this pollination mechanisms are classified as melittophily (Roubik \& Hanson 2004).

Intra-specific variation is frequent in orchid flowers (van der Pijl \& Dodson 1966). Oncidium abortivum Rchb.f. has heteromorphic flowers, including both functional and non-functional flowers in the same inflorescence (van der Pijl \& Dodson 1966, Garay 1970). Male and female flowers of Catasetum sp. and Cycnoches sp. are very different in form, size and color, sometimes having distinct male and female flowers (Romero 1991).

High morphological variation is associated with deceptive pollination systems (Ackerman \& GalarzaPérez 1991, Sabat \& Ackerman 1996, Ackerman \& Carromero 2005, Ackerman et al. 2011). Nonrewarding orchids rely on visits by naïve pollinators who are fooled due to the variation presented among individuals within the same populations (Psychilis monensis Sauleda; Aragon \& Ackerman 2003), and form and fragrances (Tolumnia variegata (Sw.) Braem; Ackerman \& Galarza-Pérez 1991). This intra-specific variation is the raw material for natural selection (Endler 1986, Tremblay et al. 2010). Without variation (at the genetic and phenotypic level) evolution cannot proceed.

We studied the pollination ecology of the neotropical epiphytic orchid Rodriguezia granadensis (Lindl.) Rchb.f. and how variation in floral traits might affect pollinator attraction. Previous studies of morphological traits (Ortiz et al. 1991) suggested and hypothesized that pink forms of $R$. granadensis should be pollinated by hummingbird while bees would pollinate the white forms. To test this hypothesis we surveyed a population of this species of orchids in their natural habitat over three flowering periods. We monitored the visit of potential pollinators, nectar production and reproductive success (pollinaria removal and fruit set) of the white and pink forms of the orchids.

Materials and Methods. Species and study site -. Rodriguezia granadensis is a twig epiphyte orchid distributed from Panama to Peru. In Colombia, it occurs on the three main mountain chains between $700-1900 \mathrm{~m}$ of altitude. It is common on cultivated fruit trees and blooms from March to September in sub-Andean forests (Ortiz et al. 1991, Calderón-Sáenz 2007). The species is polymorphic in flower color, with white and pink flowers; has a spur that originates from the labellum tissue that surrounds the lateral sepals, which often produce nectar (Ortiz et al. 1994).

The interactions between $R$. granadensis and its pollinators, within the Yotoco Nature Forest Reserve (YNFR) and surrounding protected buffer zone $\left(3^{\circ} 52^{\prime} 51.56^{\prime \prime} \mathrm{N}, 76^{\circ} 25^{\prime} 53.53^{\prime \prime} \mathrm{W}\right)$, in the Yotoco district (Valle del Cauca, Colombia), were studied. The Reserve in Cauca Valley (559 ha) represents one of the lasts remnants of the subtropical transitional forest (1200-1950 m elevation) in the eastern section of the western mountain range of the Andes (Escobar 2001).

Individuals of $R$. granadensis at YNFR are 12$15 \mathrm{~cm}$ in height, and form small modular colonies of one to 20 pseudobulbs ( $\bar{x}=5, \mathrm{SE}=0.45, \mathrm{~N}=100$ ) in a 

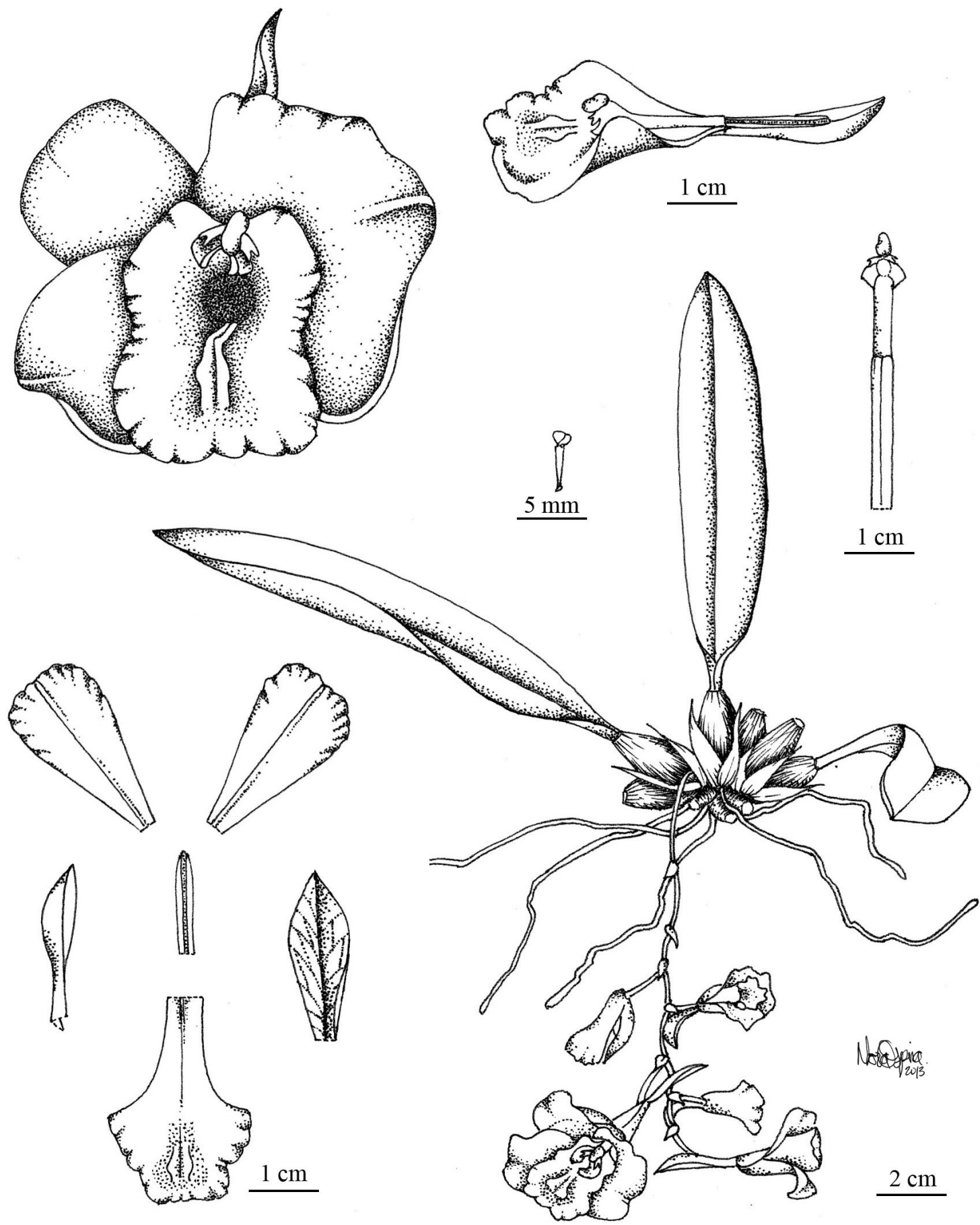

FIGURE 1. Rodriguezia granadensis plant and flower. Drawing by N. Ospina-Calderón.

phalanx growing strategy (Gibson 2002). The plants have one or two leaves on each pseudobulb, lateral pendulous inflorescences, usually with one or two inflorescences on each pseudobulb, with an average of four flowers on each inflorescence.

The flowers have a bilobed labellum, callus with 


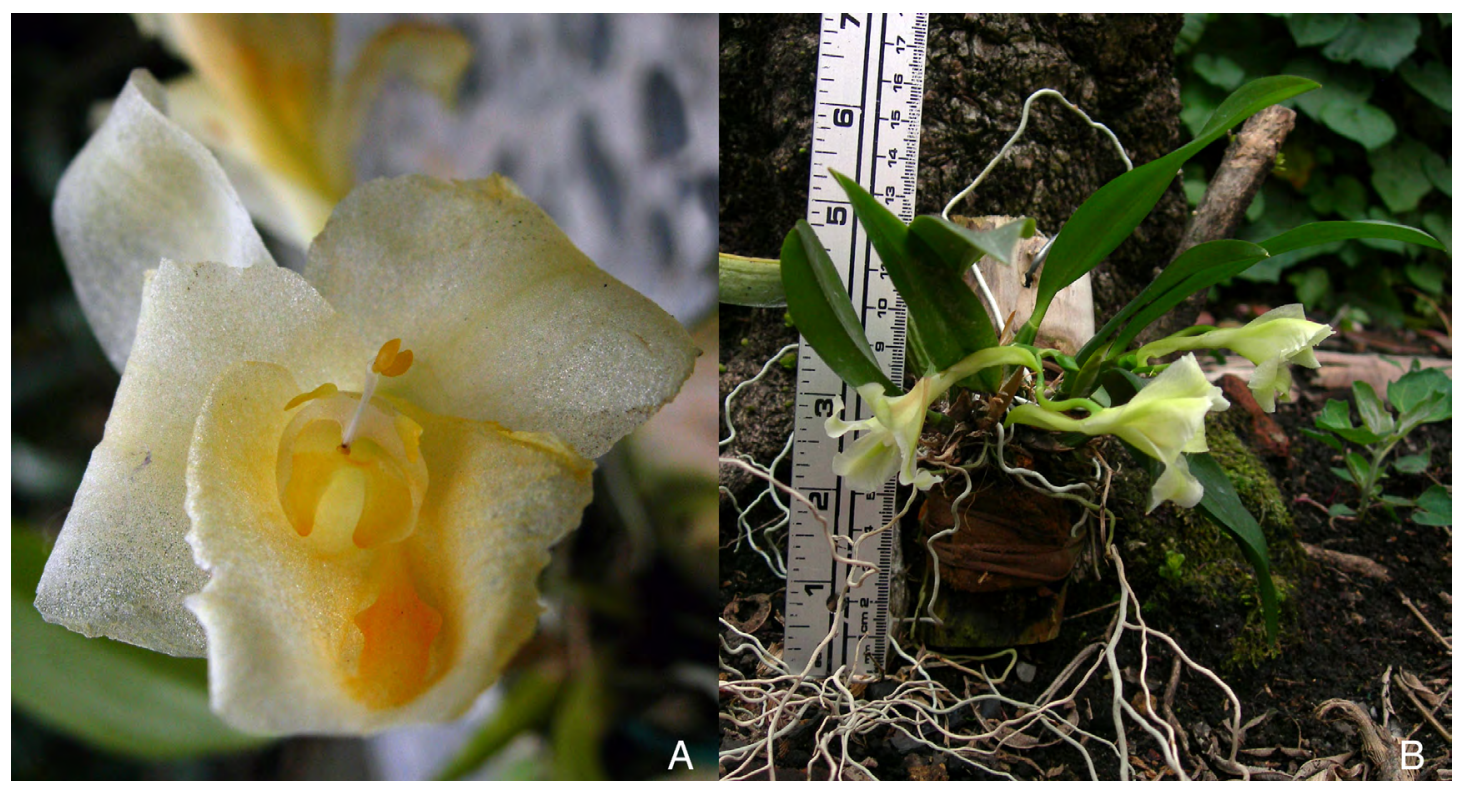

Figure 2. Photo of A. the flower and B. the habit of $R$. granadensis.

two or three lamellas, and a synsepalous spur with nectar. There is continuous variation among plants in flower color (pink to white), and flowers usually have a delicate sweet pleasant perfume (Fig. 1, 2).

Reproductive phenology and success -. During 2008 $-2009,100$ plants of $R$. granadensis were surveyed in order to describe the reproductive phenology and success. Surveys were performed monthly prior to the flowering period and weekly once flowering had initiated. Information was collected on the life stages of the plant, (flowering or not, number of flowers and fruit). Indirect evidence of reproductive potential was evaluated in open flowers as pollinaria removal for male fitness and stigma state (open or closed) for female fitness.

Flower color variation -. To evaluate floral coloration variation, digital photographs were taken of 50 flowers, 38 pink and 12 white (from 32 plants, 25 pink and 7 white), from the living orchid collection at YNFR, with in situ white balance. Four zones of the flower were chosen for the colorimetric analysis (Fig. 3) in order to characterize the different tonalities of the color in the flowers. A colorimetric analysis of the different parts of the orchid flower (zones) was performed using ACA System (2008). The color composition of each zone in the photographed flowers was standardized using the video methodology measuring base on the amount of red, green, and blue (RGB) and the printing methodology using cyan, magenta, yellow and key (CMYK) (Galer \& Horvat 2003).

Floral morphology - The variation of the species was evaluated using basic morphometric analysis (Dafni 1992) by measuring all flowers of the first season in 209, 42 flowers from 15 plants. The number of plants that flowered in the population was limited. The characters were measured in the field with a caliper and included floral width wingspread (frontal view), the length of the spur, and the length of the column. To compare the wingspread and the length of the spur between the color morphs (pink and white) a MannWhitney U test was performed because data did not have a normal distribution according to a Shapiro-Wilk test.

The nectar production was measured from 15 flowers ( 8 white, 7 pink) bagged before anthesis (March 2009, 1100-1400 hr) with a $1.15 \mathrm{~mm}$ diameter capillary. The sugar concentration was measured using a portable refractometer (Reichert BRIX 35HP). The concentration was measured as the weight of sugar/ weight of solution $\left({ }^{\circ} \mathrm{Bx}\right)$, that represents the percent sugar in the aliquot (Dafni 1992).

Pollination -. Ten plants were surveyed continuously for 15 days between $0900-1600$ hours (more than 
100 hours in 2008) during the flowering peak; a photographic and video record was made of the visitors and pollinators landing on the flowers. We recorded the number of flowers visitors per plant, pollinators' behavior, pollinaria removal, and pollinaria deposition.

Euglossine baiting traps -. Euglossine bees were captured with fragrance traps (Vélez \& Pulido-Barrios 2005). Three odor baiting traps were set up in the field with the following attractants, methyl salicylate, eugenol, and a mixture of both in the equal proportions (Otero \& Sallenave 2003, Otero \& Sandino 2003). The traps were located near the orchid population during flowering time (March to April 2010) and were checked (daily) during the day between 0800-1400 hours for 25 days. Captured bees with pollinaria were identified with the Bonilla-Gómez \& Nates-Parra (1992) and Roubik \& Hanson (2004) keys, and were deposited at the Entomological Collection Biology Program at the University of Caldas (CEBUC), Manizales, Colombia. To evaluate whether the pollinaria came from $R$. granadensis, their structure and placement on the bees were analyzed (Dressler 1976, Roubik \& Hanson 2004).

Reproductive system -. During (March to April) 2009 , the reproductive biology of $R$. granadensis was evaluated using 30 additional cultivated plants with a total of 40 flowers. Four treatments of manual pollination (autogamy, geitonogamy, xenogamy, and emasculation) were assigned randomly across flowers, and 10 flowers were assigned to each treatment (Dafni 1992). To test for autogamous pollination, flowers were self-pollinated using pollen from the same flower and bagged; to test for geitonogamous pollination, pollen from the same plant but from different flowers were used; to test for xenogamous pollination, pollen came from a different plant; and to test for apomixis, the emasculation treatment, pollen was removed from the flower and bagged without pollination. Treatments of self-fertilization were not performed because previous research has shown that plants with bagged flowers without pollination did not produced fruits (OspinaCalderón 2009).

Results. Rodriguezia granadensis formed small clusters from one to more than 20 pseudobulbs $(\bar{x}=5, s d=5$, $\mathrm{n}=100$ plants). The plants have one leaf per pseudobulb, with pendant lateral inflorescences, usually one or two inflorescences per pseudobulb, with an average of five flowers per inflorescence $(\mathrm{sd}=1.54, \mathrm{n}=42)$.

Color variation -. Flower color varied among plants from white to pink, but over six flowering seasons, no color variation was seen within an individual. Flower color did not change with the age of the flower or the result of pollination.

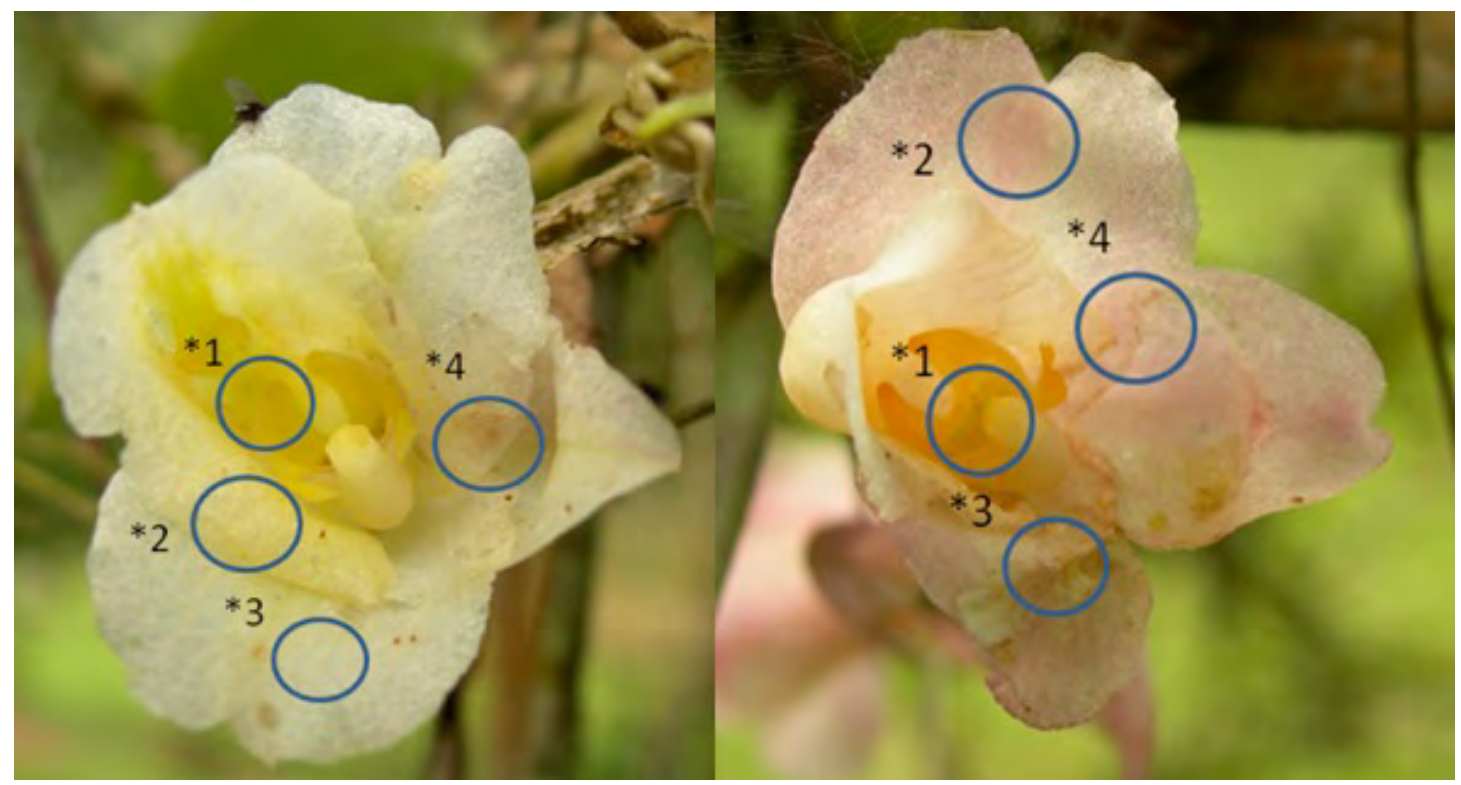

FIGURE 3. Flowers of R. granadensis, analysis of zones, with delimitation of zones for colorimetic analysis. 


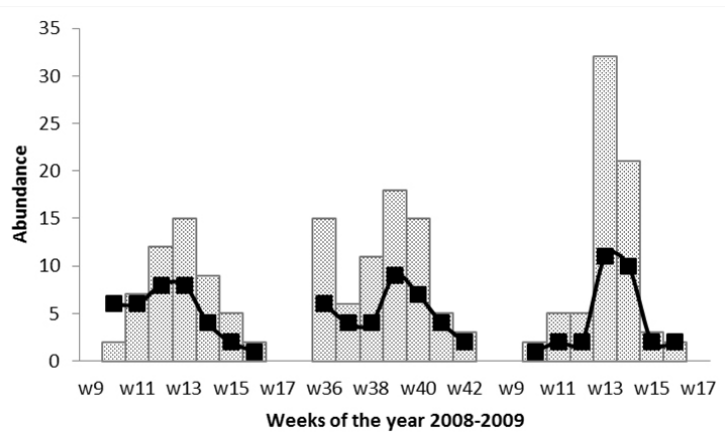

Figure 4. Reproductive phenology of $R$. granadensis by weeks in the Yotoco Nature Forest Reserve 2008-2009, Number of open flowers (bar), number of flowering plants (line).

Reproductive phenology and reproductive success -. Rodriguezia granadensis in the YNFR bloomed synchronously, twice a year, the first period starting at week ten (March-April) and the other starting at week 36 (September-October). In March 2008 eight of the 100 plants studied produced 15 flowers; in September nine plants produced 19 flowers. During March 2009 15 plants produced 42 flowers (Fig. 4). In the March 2009 flowering, the average number of flowers per plant was 3.6 (Fig. 4). Two plants flowered in both 2008 and 2009. Each flower remained open for seven days on average ( $\mathrm{sd}=0.27, \mathrm{n}=42$ ) and the population had open flowers during over a period of seven weeks. The flowering peak was the third week after the beginning of blooming, and the fruit set $11.3 \%(\mathrm{sd}=1.98, \mathrm{n}=3)$.

The observations for male and female fitness in the population were the following: in March 2008, five flowers donated pollen and two of them received it; on September 2008 five flowers donated pollen and, two received; and during March 2009, six flowers donated with three flowers receiving pollen (with closed stigmas). There were no significant differences among flower color morphs on reproductive success (Mann Whitney, $\mathrm{W}=2.00, \mathrm{p}=0.772$ ).

Floral morphology -. The average flower wingspread was $24.5 \mathrm{~mm}(\mathrm{sd}=6.79, \mathrm{n}=42)$, and spur length was $26.5 \mathrm{~mm}(\mathrm{sd}=3.17, \mathrm{n}=42)$. There were no significant difference among floral color morphs in wingspread (Mann Whitney, $\mathrm{W}=260.5 \mathrm{p}=0.12$ ), or spur length (Mann Whitney, $\mathrm{W}=192 \mathrm{p}=0.79$ ).

The mean nectar volume per plant was $1.96 \mu 1(\mathrm{sd}=$ $2.96, \mathrm{n}=14$ ) and mean sugar concentration was $31.32^{\circ}$
Brix (mass percentage of sucrose) $(\mathrm{sd}=2.87, \mathrm{n}=5)$. Not all bagged flowers had nectar, and only 15 of 42 (36\%) wild flowers contained nectar. No significant differences was noted in nectar volume among flower color morphs (Mann Whitney, W=149.5, $\mathrm{p}=0.10$ ). Additionally, a pleasant smell was detected in the all flowers. The spur was formed by two channels, which produce sugar secretions into a cavity formed by the lateral fused sepals (Fig. 5).

Pollination -. Observations of pollinators visiting flowers of $R$. granadensis were scarce. The behavior of the insects in the vicinity of nine plants and 19 flowers over more than 105 hours (seven hours a day, for 15 days) was recorded and Eulaema meriana Olivier was seen visiting two pink flowers of the same plant. The bee was observed landing on the labellum of the flower with the proboscis extended in a visit of five to ten seconds, looking for nectar, removing the pollinaria, that stick to the labrum of the bee and depositing those carried previously. Both flowers visited produced a fruit (Fig. 6a, b). These two fruits were later damaged by herbivores.

Baiting traps -. A total of 11 male euglossinae bees were captured using the odor baiting traps: with a mix of eugenol and methyl salicylate one Exaerete smaragdina Guerin-Meneville, and one Eulaema cingulata Fabricius were collected; with only methyl salicylate, five Eulaema meriana were captured (Fig. 6c); with only eugenol an additional four Eulaema cingulata were captured. From the 11 collected bees, 5 had $R$. granadensis pollinaria attached to the labrum. The one individual of Exaerete smaracdina had four pollinaria, two of them with stipe and pollinia and two stipes without pollinia. One El. meriana had two stipes and another had a complete pollinarium. Two $E l$. cingulata had each one complete pollinarium.

Reproductive system -. Rodriguezia granadensis is self-incompatible with obligated xenogamy as none of the self-pollination and geitonogamy treatments produced any fruits. Nevertheless, the self-pollination induced swollen reaction and closure of the stigma showing that the self-incompatibility is gametophytic rather than sporophytic. The emasculation treatment did not produce any fruits, suggesting that there is no apomixis in $R$. granadensis. The xenogamy treatment had $100 \%$ fruit production. 


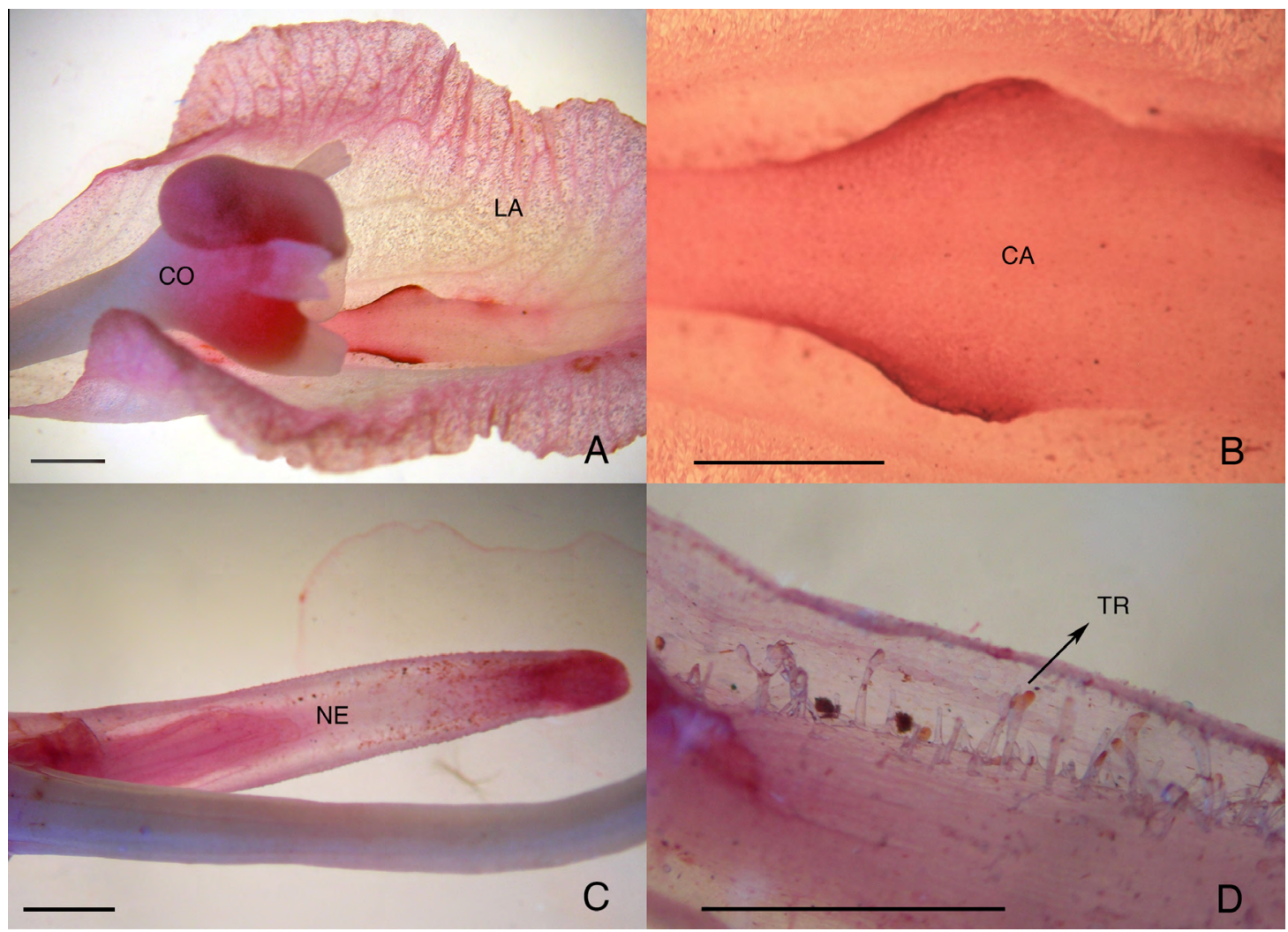

FIGURE 5. A floral morphology of $R$. granadensis with neutral red dye, A. General view, column and labellum. B. Close-up of the callus of the labellum, colored laminas; C. Nectary after removing the synsepal; D. Nectary detail column tissue enveloped in the labellum tissue, partially colored trichomas. Escale bar $=1 \mathrm{~mm} ; \mathrm{CO}=$ column; $\mathrm{LA}=$ labellum; $\mathrm{CA}=$ callus of the labellum; $\mathrm{NE}=$ nectary; $\mathrm{TR}=$ trichomes.

Colorimetry -. The studied population had 15 white and 27 pink flowers; the colors were consistent within an individual and did not change with the maturity of the flowers or the reproductive state. According to the RGB analysis, there are no differences between the color phenotypes among the plants in the population (Fig. 7), with similar values of reflection for each zone and color (Table 1). However, in the color space of CMYK there was a difference in the quantity of magenta absorbed in the region 2 (Fig. 7) analyzed from the different color morphs of $R$. granadensis. Intermediate morphs were also observed in nature in the same population and in other sites.

Discussion. Rodriguezia granadensis plants flowered synchronously twice a year at the YNFR (Fig. 4) in a massive blooming strategy (Dafni 1992, Gentry 1978). It coincides with the peak of precipitation at YNFR during the first week of April and October (CVC 2006). This synchrony between the floral phenology of the orchids and the local precipitation may be a consequence of the plant physiology and the abundance of resources of the time (Zimmerman et al. 1989). Epiphytic environments are very dry as little water is stored after rains, suggesting that water could be a limiting resource for epiphytic plants (Zotz \& Hietz 2001). Ample evidence suggests that, most tropical epiphytic species synchronize their reproduction with rain patterns (Ospina-Calderón et al. 2007, SahagúnGodinez 1996, Zimmerman et al. 1989)

Throughout the observation period, we recorded only two effective visits of Eulaema meriana to two pink flowers of $R$. granadensis on the same plant. Both flowers were pollinated as a consequence of these visits (Fig. 6). The bee had a typical feeding behavior of extending its proboscis (Barth 1991). It did not 


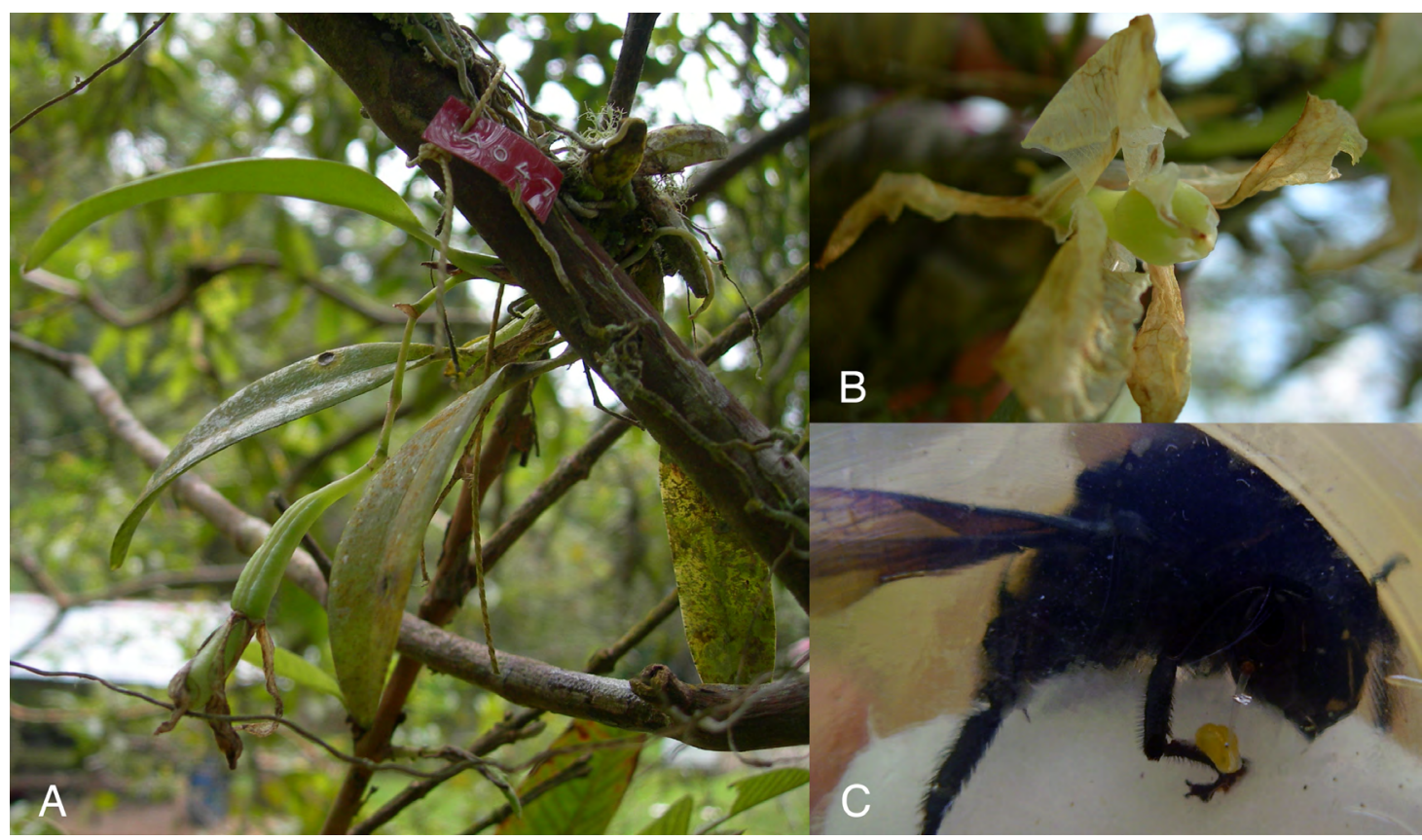

Figure 6. Pollination of R. granadensis in the Yotoco Nature Forest Reserve. A. developing fruit. B. Closed (pollinated) stigma. C. Male Eulaema meriana bearing a pollinarium of $R$. granadensis attached to the labrum.

exhibit the behavior of fragrance collecting (scratching the floral tissue) followed by hovering to put the fragrance in its hind tibia (Roubik \& Hanson 2004). Additionally, we captured males of Eulaema meriana, Eulaema cingulata and Exaerete smaracdina with pollinaria of $R$. granadensis on their labrum. These are the first observations of effective pollination in $R$. granadensis; previously, it was speculated that yellow or white flowers were pollinated by bees, while pink flowers were pollinated by birds (Ortiz et al. 1991, Ortiz et al. 1994), nevertheless, we found no evidence of bird visitation.

The lack of red coloration or contrasting colors, in the form of a tunnel or bell, zygomorphic with a nectar guide, landing platform, diurnal anthesis and odors nectar or deceptive would suggest that flowers of $R$. granadensis are melittophilic (van der Pij1 1961).

TABLE 1. Reflected color Wilcoxon tests between white and pink flowers for four colorimetric analyses zones.

\begin{tabular}{c|c|c|c}
\hline Zone B/R & W & $\mathbf{z}$ & $\mathbf{p}$ \\
\hline 1 & 13,000 & 0,524 & 0,600 \\
\hline 2 & 18,000 & 0,676 & 0,499 \\
\hline 3 & 15,500 & 0,255 & 0,799 \\
\hline 4 & 18,000 & 0,676 & 0,499 \\
\hline
\end{tabular}

Rodriguezia granadensis is an obligated xenogamic species with gametophytic self-incompatibility (none of the plants fertilized by autogamy developed fruits). Self-pollen treatment deposition results in flower wilting and the stigma closing around the pollinia (Dafni 1992), but the fruit does not develop (LovettDoust \& Lovett-Doust 1988).

The spur of $R$. granadensis presents an average length of $26.5 \mathrm{~mm}$ while the E. meriana can have a proboscis up to $40 \mathrm{~mm}$, and it is known that euglossine bees forage a wide diversity of tubular flowers of different depth (Roubik \& Hanson 2004, Otero \& Sandino 2003).

Thirty six percent of the $R$. granadensis flowers possessed nectar, at a high sugar concentration (33\%). Nectar volumes were greater than those observed in Rodriguezia bahiensis with only $0.4 \mu 1$ and $16.5 \%$ of sugar (Carvalho \& Machado 2006). R. bahiensis is known to be pollinated by flies and visited by bees. The quantity and quality of nectar found in $R$. granadensis is in the reported range foraged by euglossines $(0.003 \mu 1-120 \mu 1)$, with similar high variation in sugar concentration, $5-75 \% \mathrm{w} / \mathrm{w}$. However, these bees are not known to consume highly concentrated nectar (Borrell 2005, Borrell 2006). 

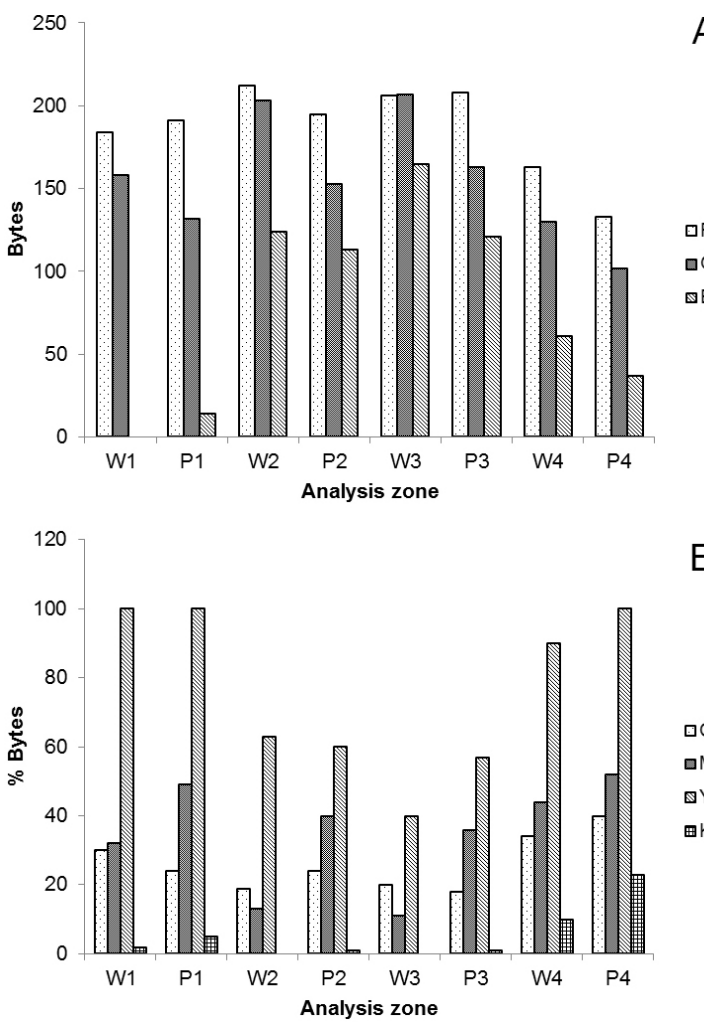

Figure 7. A. Flowers of $R$. granadensis, analysis of four zones for color morph, white to pink (W1, P1; W2, P2; W3, P3; W4, P4) RGB space, additive, spectrum intensity of the reflected light. R, Red, G, Green, B, Blue. B. CMYK space C, Cyan, M, Magenta, Y, Yellow, $\mathrm{K}$, Key or black.

Sixty four percent of the flowers of $R$. granadensis studied had no nectar. Thus, most of the flowers of this population are deceptive. Given this variation in nectar presence, it is possible that this species has an attraction system that is 'self-mimetic' or a diffuse rewarding phenomenon (Jersáková et al. 2006, Ackerman 1986b). This would assume that pollinators that follow planned routes to forage and do probe deceptive flowers do occasionally find rewards (Jersáková et al. 2006, Ackerman 1986b), at least sufficiently frequently to merit continuous exploration. Other studies focused on determining if there is frequency dependent selection for the polymorphic condition in deceit pollination systems, showed that pollinators can learn, and the presence of deceitful flowers may influence positively reproductive success in mix rewarding system (Ospina-Calderón et al. 2007,
A Ackerman \& Carromero 2005, Aragon \& Ackerman 2003, Ackerman et al. 1997, Sabat \& Ackerman 1996, Ackerman \& Galarza-Pérez 1991).

In Comparettia falcata, another nectariferous orchid, the production of nectar is not necessary a good indicator of reproductive success (Ackerman et al. 1994, Rodríguez-Robles et al. 1992). In this case, the pollinators, a hummingbird, is apparently sensitive to lack of nectar (Ackerman et al. 1994), however, does not respond to nectar supplementation (SalgueroFaría \& Ackerman 1999). The lack of nectar in some individuals of $R$. granadensis suggest that individuals with or without nectar may have the same reproductive success and consequently, fitness of individuals with nectar may not differ from those that lack nectar. If there is a high cost to producing nectar then it is likely that there could be a disadvantage, and these individuals would result in a lower lifetime reproductive success. It is possible that they only bloom during the rainy season because water as is a limiting resource, and nectar may only be produced when sufficient water is available. Additionally, the production of too many fruits may attract seed predators (Ackerman \& Montalvo 1990), making a limited fruit set a more effective reproductive strategy.

The fragrance of $R$. granadensis is one of the features that suggests melittophily (van der Pijl 1961) and it is also the floral attractive agent for other orchids, including polymorphic Tolumnia variegata, a food deceptive, twig epiphytic orchid pollinated by the bee Centris versicolor (Ackerman et al. 1997).

Our pollination data are too few to adequately test the hypothesis that euglossine bees pollinate both colors morphs (pink and white) of $R$. granadensis, based on the quality and quantity of the reward offered. Our data do not agree with the published hypothesis suggesting the pink morphs of $R$. granadensis are pollinated by hummingbirds (Ortiz et al. 1991). However, because of the widespread geographic distribution of this species, the possibility of other pollinators for this species cannot be discounted. Variation in nectar volume suggests the species may be a useful model to evaluate further evolutionary questions relating to the transition between rewarding and deceitful pollination systems.

Acknowledgments. These data are part of Master thesis in Biological Sciences-Ecology presented to the 
Universidad Nacional de Colombia by the first author with the support of the Research Group in Orchids, Ecology and Plant Systematics (Colciencias: COL0066015). The study was accomplished thanks to the logistical support of the YNFR, IDEA Palmira, UNAL. We thank two anonymous reviewers, Mark Whitten, James Ackerman, Jana Jersáková, Nicola S. Flanagan, Guiomar Nates-Parra, Marisol Amaya, Argenis Bonilla, Peter Wüllner, Norris
Williams, Favio González, Gustavo Adolfo Jiménez, Jorge Humberto Ramírez, Masanobu Tsubota, Valentín Hidalgo, Hernán Ospina, Julia Calderón, Luis Fernando Ospina, José Joaquín Varela, Julián Farfán, Mónica Castillo, Marcela Cuartas-Domínguez, Camilo Cadena, Alejandro Calderón, Alexander Castiblanco, Víctor Peña-León, Cristian Delgado, Liliana León, Cristina Bejarano, Luis Eduardo Caballero, Agustina Ventre.

\section{LITERATURE CITED}

Aca System. (2008). Color piker software, ACA Color Picker. [on líne] http://www.acasystems.com/en/color-picker/ July 10, 2008, (consulted May 2009).

Ackerman, J. D. (1986a). Coping with the epiphytic existence: pollination strategies. Selbyana, 9, 52-60.

Ackerman, J. D. (1986b). Mechanism and evolution of food-deceptive pollination system in orchids. Lindleyana, 1, 108113.

Ackerman, J. D. \& Carromero, W. (2005). Is reproductive success relates to color polymorphism in a deception pollinated tropical terrestrial orchid?. Caribbean Journal of Science, 41, 234-242.

Ackerman, J. D., Cuevas, A. A. \& Hof, D. (2011). Are deception -pollinated species more variable than those offering reward?. Plant Systematics and Evolution, 293, 91-99.

Ackerman, J. D. \& Galarza-Pérez, M. (1991). Patterns and maintenance of extraordinary variation in the Caribbean orchid, Tolumnia (Oncidium) variegata. Systematic Botany, 16:182-194.

Ackerman, J. D., Meléndez-Ackerman, E. \& Salguero-Faría, J. (1997). Variation in pollinator abundance and selection on fragrance phenotypes in an epiphytic orchid. American Journal of Botany, 84, 1383-1390.

Ackerman, J. D., \& Montalvo, A. M. (1990). Short-and long-term limitations to fruit production in a tropical orchid. Ecology, 71, 263-272.

Ackerman, J. D., Rodríguez-Robles, J. A. \& Meléndez, E. J. (1994). A meager nectar offering by an epiphytic orchid is better than nothing. Biotropica, 26, 44-49.

Aragon, S. \& Ackerman, J. D. (2003). Does flower color variation matter in deception pollinated Psychilis monensis (Orchidaceae)?. Oecologia, 138, 405-413.

Barth, F. G. (1991). Insects and flowers, the biology of a partnership. Princeton, New Jersey: Princeton University Press.

Bonilla-Gómez, M. A. \& Nates-Parra, G. (1992). Abejas euglosinas de Colombia (Hymenoptera: Apidae) I. Claves ilustradas. Caldasia, 17, 149-172.

Borrell, B. J. (2005). Long tongues and loose niches: evolution of euglossine bees and their nectar flowers. Biotropica, 37, $664-669$.

Borrell, B. J. (2006). Mechanics of nectar feeding in the orchid bee Euglossa imperialis: pressure, viscosity and flow. Journal of Experimental Biology, 209, 4901-4907.

Calderón-Sáenz, E. (2007). Libro rojo de plantas de Colombia. Volumen 6: Orquídeas, primera parte. Bogotá, Colombia: Instituto de Investigación de Recursos Biológicos Alexander von Humboldt.

Carvalho, R. \& Machado, I. C. (2006). Rodriguezia bahiensis Rchb. f.: biologia floral, polinizadores e primeiro registro de polinização por moscas Acroceridae em Orchidaceae. Revista Brasileira de Botânica, 29, 461-470.

Cuartas-Domínguez, M. \& Medel, R. (2010). Pollinator-mediated selection and experimental manipulation of the flower phenotype in Chloraea bletioides. Functional Ecology, 24, 1219-1227.

CVC. (2006). Corporación autónoma regional del Valle del Cauca, Boletín hidroclimatológico 2006, Dirección técnica ambiental, grupo de sistemas de monitoreo ambiental, red de hidroclimatología. www.cvc.gov.co/vsm38cvc/. (consulted February 2009).

Dafni, A. (1992). Pollination ecology: a practical approach. Oxford.: Oxford University Press.

Dressler, R. L. (1976). How to study orchid pollination without any orchids. In: K. Senghas (Ed.), Proceedings of the 8th World Orchid Conference (pp. 534-537). Frankfurt: German Orchid Society Inc.

Endler, J. A. (1986). Natural selection in the wild. U.S.A: Princeton University Press.

Escobar, E. (2001). Presentación de Yotoco "Reserva Natural": flora: plantas vasculares. Palmira, Colombia: Editorial Universidad Nacional de Colombia.

Galer, M., \& Horvat, L. (2003). Digital Imaging: Essential Skills. U.S.A.: Focal Press.

Garay, L. A. (1970). A Reappraisal of the Genus Oncidium Sw. Taxon, 19, 443-467. 
Gentry, A. (1978). Antipollinators for mass flowering. Biotropica, 10, 68-69.

Gibson, D. J. (2002). Method in comparative plant population ecology. New York, U.S.A.: Oxford University Press.

Gravendeel, B., Smithson, A., Slik, F. \& Schuiteman, A. (2004). Epiphytism and pollinator specialization: drivers for orchid diversity?. Philosophical Transactions of the Royal Society B, 359, 1523-1535.

Jersáková, J., Johnson, S. \& Kindlmann, P. (2006). Mechanism and evolution of deceptive pollination in orchids. Biological Reviews, 81, 219-235.

Jersáková, J. \& Kindlmann, P. (2004). Reproductive success and sex variation in nectarless and rewarding orchids. International Journal of Plant Sciences, 165, 779-785.

Lovett-Doust, J. \& Lovett-Doust. L. (1988). Plant Reproductive Ecology. New York: Oxford University Press.

Medel, R., Aizen, M. \& Zamora, R. (2009). Ecología y evolución de interacciones planta-animal. Chile: Editorial Universitaria.

Ortiz, P., Aguirre, G. A., Arango, A., Arango, C., Bock, I., Bockemühl, L., Dodson, C. H., Dressler, R. L., Escobar, R., Folsom, J. P., Gerlach, G., Hágsater, E., Luer, C. A., Neudecker, T. \& Vieira, L. C. (1994). Native Colombian Orchids. Volume I: Acacallis - Dryadella. Colombia: Editorial Colina.

Ortiz, P., Aguirre, G. A., Atwood, J. T., Bockemühl, L., Dodson, C. H., Hágsater, E., Jenny, R., Luer, C. A., Neudecker, T., Posada, J. F., Ruiz, G. \& Vieira, L. C. (1991). Orquídeas nativas de Colombia Volumen III: Maxillaria - Pontieva. Colombia: Editorial Colina.

Ospina-Calderón, N. H. (2009). Selección de rasgos florales en Rodriguezia granadensis (Lindl.) Rchb.f. (Orchidaceae): Estudio de la eficacia biológica en una especie polimórfica. (Tesis inédita de maestría). Universidad Nacional de Colombia, Bogotá, Colombia.

Ospina-Calderón, N. H., Diazgranados, M. \& Riveros, P. A. (2007). Observaciones de la polinización y fenología reproductiva y de Brassia cf. antherotes Rchb. f. (Orchidaceae) en un relicto de selva subandina en la Reserva Natural La Montaña del Ocaso en Quimbaya, Quindío (Colombia). Universitas Scientiarum, 12, 83-95.

Otero, J. T. \& Sallenave, A. (2003). Vertical stratification of euglossine bees (Hymenoptera: Apidae) in an Amazonian forest. The Pan-Pacific Entomologist, 79, 151-154.

Otero, J. T. \& Sandino, J. C. (2003). Capture rates of male euglossine bees across a human intervention gradient, Choco region, Colombia. Biotropica, 35, 520-529.

Rodríguez-Robles, J. A., Meléndez, E. J. \& Ackerman, J. D. (1992). The effects of display size, flowering phenology, and standing crop of nectar on the visitation frequency of Comparettia falcata (Orchidaceae). American Journal of Botany, 79, 1009-1017.

Romero, G. A. (1991). Orquídeas unisexuales. Investigación y Ciencias, 172, 66-75.

Roubik, D. W. \& Hanson, P. E. (2004). Orchid bees of tropical America: biology and field guide. Heredia, Costa Rica: InBIO Press.

Sabat, A. \& Ackerman, J. D. (1996). Fruit set in a deceptive orchid: the effect of flowering phenology, display size, and local floral abundance. American Journal of Botany, 83, 1181-1186.

Sahagún-Godinez, E. (1996) Trends in the phenology of flowering in the Orchidaceae of Western Mexico. Biotropica, 28, $130-136$.

Salguero-Faría, J. \& Ackerman, J. D. (1999). A nectar reward: is more better?. Biotropica, 31, 303-311.

Tremblay, R. L., Ackerman, J. D., \& Pérez, M. E. (2010). Riding across the selection landscape: fitness consequences of annual variation in reproductive characterisitics. Philosophical Transactions of the Royal Society B, 365, 491-498.

Tremblay, R. L., Ackerman, J. D., Zimmerman, J. \& Calvo, R. (2005). Variation in sexual reproduction in orchids and its evolutionary consequences: a spasmodic journey to diversification. Biological Journal of the Linnean Society, 84, 1-54.

Van der Pijl, L. (1961). Ecological aspects of flower evolution. II. Zoophilous flower classes. Evolution, 15, 44-59.

Van der Pijl, L. \& Dodson, C. H. (1966). Orchid flowers: their pollination and evolution. Florida, U.S.A: University of Miami Press.

Vélez, D. \& Pulido-Barrios, H. (2005). Observaciones sobre la estratificación vertical de abejas Euglosinas (Apidae:Euglossini) en un bosque ripario de la orinoquía colombiana. Caldasia, 27, 267-270.

Zimmerman, J. K., Roubik, D. \& Ackerman, J. D. (1989). Asynchronous phenologies of a neotropical orchid and its euglossine bee pollinators. Ecology, 70, 1192-1195.

Zotz, G., \& Hietz, P. (2001). The physiological ecology of vascular epiphytes: current knowledge, open questions. Journal of Experimental Botany, 52, 2067-2078. 